\title{
Unit per Milligram of Protein
}

National Cancer Institute

\section{Source}

National Cancer Institute. Unit per Milligram of Protein. NCI Thesaurus. Code C73782.

An arbitrary unit of substance concentration expressed in unit(s) per milligram of protein. 